\title{
IMPLEMENTASI SISTEM INFORMASI YAYASAN (SIYAP) TERHADAP KUALITAS TATA KELOLA KEUANGAN YAYASAN PENDIDIKAN ISLAM DI JEPARA
}

\author{
A. Khoirul Anam ${ }^{1)}$, Muhammad Ridho ${ }^{2)}$, Fatchur Rohman ${ }^{3)}$ \\ 1,2,3) Fakultas Ekonomi dan Bisnis, Universitas Islam Nahdlatul Ulama \\ 1) Email: ridhodaren80@unisnu.ac.id \\ 2)Email:anam@unisnu.ac.id \\ ${ }^{3)}$ Email: fatchur@unisnu.ac.id
}

\begin{abstract}
ABSTRAK
Artikel ini memaparkan hasil kegiatan pengabdian kepada masyarakat program Iptek Bagi Masyarakat (IbM) pada Yayasan Pendidikan Islam di Jepara yang menghadapi masalah pengelolaan keuangan. Adapun tujuan dari program pengabdian masyarakat ini yaitu implementasi sistem informasi yayasan (SIYap) dan manajemen tatakelola keuangan yayasan. Tahap pelaksanaan program yang dilaksanakan meliputi: 1) Pengembangan sistem informasi yayasan (SIYap); 2) Penerapan dan proses implementasi aplikasi SIYap; 3) Penyusunan dan implementasi prosedur mutu tatakelola keuangan; 4) Pendampingan dan penerapan manajemen tatakelola keuangan. Dari hasil program pengabdian dihasilkan output luaran berupa aplikasi Sistem Informasi Yayasan (SIYap) dan dokumen Prosedur Mutu tatakelola keuangan yayasan. Berdasarkan pada hasil pengabdian dapat dirumuskan bahwa implementasi Sistem Informasi Yayasan (SIYap) dapat meningkatkan kualitas tatakelola keuangan yang ada di yayasan yang dijadikan objek pengabdian, hal ini dilihat dari pengelolaan keuangan di masing-masing unit dilakukan dengan baik, kualitas penyajian laporan keuangan sesuai dengan standar akuntansi, pelaporan yayasan sesuai dengan format dan memenuhi ketepatan waktu pelaporan.
\end{abstract}

Kata Kunci : sistem informasi yayasan, prosedur mutu, tata kelola keuangan

\section{PENDAHULUAN}

Terbitnya Undang-Undang (UU) Nomor 16 Tahun 2001 yang kemudian diubah dengan UU Nomor 28 Tahun 2004 tentang Yayasan, menjadikan yayasan memiliki landasan hukum yang kuat. Namun, pendirian yayasan tak jarang hanya didasarkan atas kebiasaan dalam masyarakat dan yurisprudensi Mahkamah Agung. Adanya kecenderungan di masyarakat, mendirikan yayasan dengan maksud tidak hanya sebagai wadah pengembangan kegiatan sosial, namun terdapat maksud lain, misalnya dalam bentuk memperkaya diri para pendiri, pengurus, dan pengawas. Akhirnya menimbulkan berbagai masalah karena tidak lagi sesuai dengan Anggaran Dasar (AD), munculnya sengketa antara pengurus dengan pendiri, maupun yayasan digunakan untuk menampung kekayaan yang diperoleh dengan cara melawan hukum.

Banyak sebab mengapa yayasan dalam perjalannya menyimpang dari tujuan filosofis pendiriannya. Pertama, berkaitan dengan definisi kegiatan sosial, banyak yang sulit memahaminya, termasuk dalam hal ini lembaga pendidikan sebagai lembaga sosial, karena bagaimanapun kenyataanya banyak institusi pendidikan yang mengejar keuntungan. Kedua, berkaitan dengan peraturan perundang-undangan. Dalam peraturan perundangan ditemukan ketentuan yang mensyaratkan pelaksanaan suatu kegiatan harus dilakukan oleh lembaga berbadan hukum yayasan. Di sektor pendidikan, pelaksanaan sekolah swasta harus dikelola oleh yayasan. Bagi mereka yang ingin mendirikan lembaga pendidikan untuk tujuan komersial tentunya tidak mempunyai pilihan lain selain menggunakan yayasan sebagaimana dipersyaratkan oleh peraturan perundang-undangan. Ketiga, Yayasan diselenggarakan sebagaimana layaknya PT. Seseorang mendirikan yayasan dengan maksud untuk mencari keuntungan baik langsung maupun tidak langsung.

Pengembangan kegiatan sosial yang dilakukan oleh yayasan antara lain menyelenggarakan pendidikan. Berdasarkan data dari kantor Dinas Pendidikan, Pemuda dan Olahraga dan Kantor Kementerian Agama Kabupaten Jepara, pada tahun 2013 tercatat ada 342 Yayasan dimana 224 sudah memenuhi ketentuan Undang-Undang yayasan dimana ada pengesahan dari kementrian hukum dan HAM dan selebihnya sebanyak 118 masih sebatas dengan menggunakan akta notaris saja. Dari seluruh yayasan tersebut sebagian besar mengelolaan lembaga pendidikan dari mulai pendidikan formal 
yaitu RA/TK, MI, SLTP/Mts, SLTA/MA, dan Perguruan Tinggi, sedangkan ada pula yayasan yang juga mengelola lembaga pendidikan non formal misalnya pondok pesantren dan lembaga pelatihan kerja.

Dalam praktiknya penyelenggaraan pendidikan yang diselenggarakan oleh yayasan, banyak pengurus yayasan yang ikut mengatur semua kebijakan yang menyangkut bidang administrasi umum dan keuangan, bahkan turut campur pula dalam bidang akademik. Turut campurnya pengurus yayasan dalam penentuan kebijakan bidang keuangan ini menimbulkan potensi konflik antara pengurus yayasan dengan pengelola lembaga pendidikan yang berada dibawah yayasan tersebut, sehingga perlunya imlementasi tatakelola keuangan yang baik oleh yayasan. Penerapan tatakelola kelembagaan yang baik (Good corporate governance/GCG) untuk menghindarkan dari adanya konflik dan pertentangan. GCG pada prinsipnya tidak saja mengembangkan kode etik dan prinsip untuk menghindari kejahatan dan pertentangan, tetapi menyangkut pula tentang keterbukaan, tidak diskriminatif, tanggungjawab yang jelas dan ada media kontrol masyarakat (Karyono, 2013).

Mekanisme Good corporate governance dianggap sebagai faktor terpenting dalam menilai dan memantau keefektifan pelaporan keuangan (Brown, 2014), Tatakelola internal dan eksternal yang ditetapkan oleh lembaga untuk meningkatkan efisiensi dan efektivitas operasi dan mengurangi timbulnya kesalahan atau manipulasi dalam sistem akuntansi (Lee, 2006 dalam Almasarwah, 2015). Guna meningkatkan efisiensi dan efektivitas serta mengurangi timbulnya kesalahan dalam pengelolaan dan penyajian laporan keuangan, maka dapat dilakukan melalui implementasi sistem informasi.

Penggunaan teknologi informasi dalam pengelolaan keuangan Yayasan di kabupaten Jepara masih sangat terbatas. Dari 224 yayasan yang telah mendapatkan pengesahan dari Kementerian Hukum dan HAM hanya $10 \%$ yang sudah menerapkan teknologi informasi dalam mengelola administrasi dan pengelolaan keuangan. Hal ini tidak terlepas karena keterbatasan kemampuan yayasan dalam mengadakan sarana teknologi informasi dan kemampuan sumber daya manusia yang ada di yayasan dalam penguasaan teknologi informasi yang masih minim.

Kegiatan pengabdian masyarakat ini dilaksanakan pada dua mitra yayasan, dari 224 yayasan yang telah mendapatkan pengesahan dari Kementerian Hukum dan HAM dimana menurut pengabdi sangat membutuhkan pendampingan dan bersedia untuk dijadikan Mitra kegiatan Iptek bagi Masyarakat. Pertama adalah Yayasan Pendidikan Islam (YPI) Masalikil Huda, merupakan yayasan swasta yang beroperasi pada tahun 1995 dan telah mendapatkan pengesahan dari kementerian hukum dan HAM dengan nomor pengesahan No. AHU6482.AH.01.04 tahun 2010, YPI Masalikil Huda mengelola lembaga pendidikan mulai tingkat MI, MTs dan MA. Beralamat di Jl. Soekarno Hatta Km.05 Tahunan Kode Pos 59427 Kabupaten Jepara. Kedua adalah Yayasan Pendidikan Islam (YPI) Miftahul Huda, merupakan yayasan swasta yang beroperasi sejak tahun 1980, YPI Miftahul Huda mengelola lembaga pendidikan mulai tingkat PAUD, TK dan MI. Beralamat di Desa Sinanggul RT.39 RW 08 Jepara.

Adapun persoalan yang di hadapi oleh kedua mitra yaitu berkaitan dengan masalah pengelolaan administrasi, secara umum menjadi kendala mitra, meskipun sudah dikelola namun masih manual, hal ini menjadikan kendala ketika menyusun laporan ataupun dalam kebijakan pengambilan keputusan. Dalam pelaksanaan pengelolaan administrasi juga sangat tergantung kepada petugas administrasi yang jumlah dan kemampuanya masih terbatas.

Untuk itu perlu dikembangkan sebuah sistem informasi yang dapat menunjang pengelolaan administrasi secara terkomputerisasi, sehingga pengelolaan administrasi dapat dilaksanakan secara efektif dan efisien. Pengembangan sistem informasi saat ini sudah menjadi kebutuhan, hanya saja mitra menghadapi kendala berkaitan dengan anggaran dan sumber daya manusia yang melakukan pengembangan dan pengelolaannya, untuk itu bersama mitra sepakat untuk menyelesaikan permasalahan pengelolaan administrasi melalui pengembangan sistem informasi manajemen tatakelola kelembagaan terpadu berbasis teknologi informasi dan komunikasi melalui program IbM.

Berkaitan dengan pengelolaan dan pelaporan keuangan persoalan yang dihadapi adalah pengembangan lembaga pendidikan yang ada di bawah yayasan tersebut sangat lamban, hal ini dikarenakan informasi yang berkaitan dengan keuangan kurang akurat. Penyebabnya diantaranya karena pelaporan keuangan masih menggunakan pelaporan secara manual, administrasi dan tatakelola keuangan yang dilakukan masih menggunakan aplikasi Excel sederhana, serta penyusunan pelaporan keuangan belum sesuai standar akuntansi. 
Pengelolaan dan pelaporan keuangan yayasan secara akurat dan akuntabel menjadi kebutuhan mendesak yang perlu segera ditangani. Banyaknya lembaga yang dikelola serta kompleksitas pelaporan yang disusun oleh masing-masing lembaga di bawah yayasan tersebut pada umumnya tidak standar, hal ini menjadikan kesulitan dalam penyusunan laporan di tingkatan pengurus yayasan, serta kesulitan berkaitan dengan perencanaan dan pengelolaan keuangan. Untuk itu bersama mitra sepakat untuk menyelesaikan permasalahan pengelolaan dan pelaporan keuangan melalui pengembangan sistem informasi manajemen tatakelola kelembagaan terpadu berbasis teknologi informasi dan komunikasi melalui program IbM.

Manajemen mutu dan tatakelola kelembagaan yang baik menjadi tuntutan bagi setiap organisasi agar dapat bersaing dan mendapatkan tempat di hati masyarakat. Untuk menjadikan agar setiap bagian berjalan sebagaimana fungsinya dan setiap karyawan bekerja sesuai tupoksinya, sehingga tujuan organisasi dapat tercapai. Untuk itu diperlukan suatu standar operasional pengelolaan yang menjadi dasar kebijakan dan kegiatan operasional yang dipedomani oleh setiap karyawan.

\section{METODE KEGIATAN}

Program dilaksanakan melalui tahapan sebagai berikut: 1) Pengembangan sistem informasi yayasan (SIYap); 2) Penerapan dan proses implementasi aplikasi SIYap; 3) Penyusunan prosedur mutu tatakelola keuangan; 4) Implementasi prosedur mutu tatakelola keuangan; 5) Pendampingan dan penerapan manajemen tatakelola keuangan.

Proses pengambangan sistem yang dilaksanakan menggunakan pendekatan system development life cycle/SDLC (Jogiyanto, 2009), melalui tahapan: 1) studi pendahuluan; 2) studi kelayakan; 3) memahami sistem yang ada; 4) perancangan sistem; 5) implementasi dan operasional sistem. Sedangkan dalam proses identifikasi masalah menggunakan kerangka PIECES (Performance, Information, Economic, Control, Efficiency dan Service).

Sesuai dengan pendekatan pengembangan system model SDLC maka dalam kegiatan pengembangan dan implementasi sistem informasi manajemen yayasan (SIYap) dilaksanakan dengan tahapan sebagai berikut:

- Melakukan analisis sistem, mengidentifikasi permasalahan dan kebutuhan pemakai;

- Perancangan sistem;

- Pengembangan sistem;
- Membuat buku manual sistem informasi manajemen tatakelola kelembagaan;

- Pelatihan operasional penggunaan Software bagi tenaga operator pelaksana sistem nantinya;

- Penerapan dan pendampingan dalam menggunakan sistem di tempat mitra.

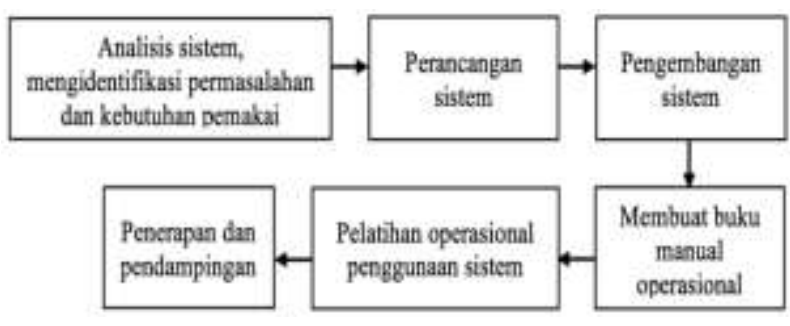

Gambar 1. Alur kegiatan pengembangan dan implementasi sistem informasi yayasan (SIYap)

Sedangkan kegiatan penyusunan sistem manajemen mutu tatakelola kelembagaan dilaksanakan melalui tahapan sebagai berikut:

- Gap analisis sistem manajemen tatakelola kelembagaan, kegiatan ini bertujuan untuk menemukan kelemahan dan kekuatan dari sistem tatakelola manajemen di tempat mitra, serta prespektif kedepan yang akan dicapai oleh mitra;

- Analisa data dari hasil gap analisis;

- Workshop hasil gap analisis untuk mendapatkan masukkan baik dari pimpinan maupun dari pelaksana, workshop diharapkan dapat digunakan sebagai bahan untuk penyusunan sistem Tatakelola manajemen sekolah, workshop ini bertujuan sebagai bahan menyusun draft rancangan sistem manajemen mutu tatakelola kelembagaan serta tentang isuisu strategis, kondisi mitra dan arah pengembangan menuju sekolah ke depan;

- Penyusunan rancangan sistem manajemen tatakelola kelembagaan;

- Workshop hasil rancangan sistem, workshop ini bertujuan untuk mendapatkan masukan untuk perbaikan selanjutnya;

- Sosialisasi kepada seluruh komponen yang ada di mitra;

- Penerapan dan pendampingan dalam menggunakan Sistem manajemen tatakelola kelembagaan di tempat mitra. 


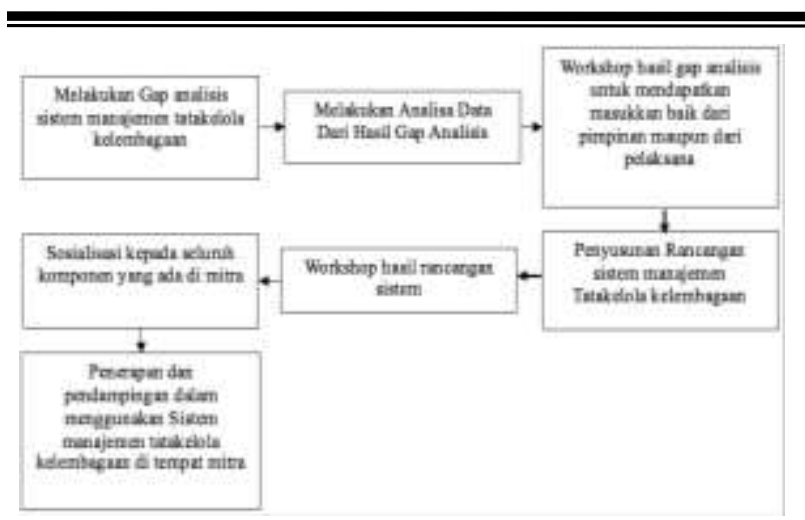

Gambar 2. Alur kegiatan penyusunan system manajemen mutu tatakelola kelembagaan

\section{HASIL DAN PEMBAHASAN}

Kegiatan pengabdian kepada masyarakat yang dilaksanakan di YPI Masalikil Huda dan YPI Miftahul Huda, dengan program sebagai berikut: 1) Kegiatan survei awal dan persiapan pelaksanaan pengabdian; 2) Pengembangan Sistem Informasi Yayasan; 3) Penyerahan Peralatan; 4) Pelatihan Sistem Informasi Yayasan; dan 5) Penyusunan Dokumen Sistem Manajemen Mutu Yayasan.

\section{1) Kegiatan survei awal dan persiapan pelaksanaan pengabdian}

Pada kegiatan ini dilakukan pertemuan awal dengan perwakilan pengurus YPI Masalikil Huda dan YPI Miftahul Huda (Gambar 1), pertemuan tersebut menghasilkan rencana kegiatan pengabdian berupa kegiatan pengembangan system informasi yayasan, penyusunan manajemen mutu pengelolaan keuangan; pengadaan peralatan serta pelatihan dan rencana implementasi dari pengembangan system tersebut.

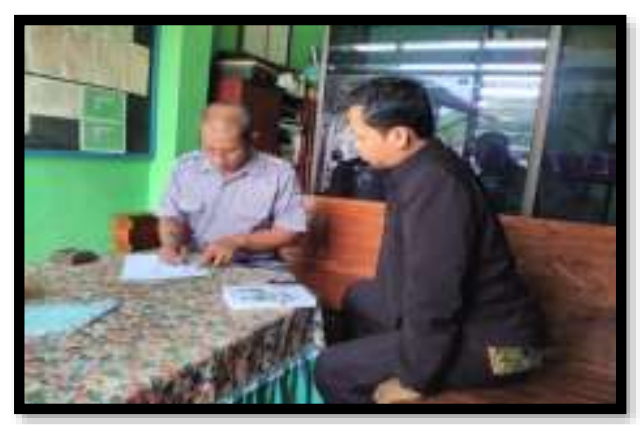

Gambar 3. Kegiatan survey awal dengan YPI Miftahul Huda

\section{2) Penyusunan Sistem Informasi Yayasan (SiYap)}

Penyusunan sistem informasi yayasan, tahap awal pelaksanaan yaitu melakukan studi pendahuluan, melalui identifikasi berkaitan dengan jenis, ruang lingkup dan pemahaman awal dari pengembangan sistem informasi yayasan. Dari studi pendahuluan ini diperoleh hasil ruang lingkup sistem yang akan disusun yaitu meliputi kebutuhan data siswa, data guru jenis transaksi dan pembayaran dan pelaporan keuangan dan akuntansi.

Tahap berikutnya yaitu melakukan studi kelayakan utamanya berkaitan dengan aspek teknologi dan operasional. Dalam hal ini didapatkan hasil pengembangan sistem dengan framework CodeIgniter, dari sisi kelayakan operasional memiliki performa lebih cepat, konfigurasi yang minim serta dokumentasi yang lengkap.

Kemudian mengidentifikasi permasalahan dan menginventarisasi kebutuhan informasi pemakai, dengan mempelajari proses bisnis yang dijalankan, mengidentifikasi permasalahan yang muncul dari proses bisnis tersebut dan memperbaiki proses bisnis yang ada. Memahami sistem yang pada prinsipnya adalah melakukan analisis kebutuhan sistem dengan menitikberatkan pada bagaimana mengidentifikasi masalah dari sistem lama yang digunakan sebelumnya, hal ini agar permasalahan yang muncul pada sistem yang lama dapat diperbaiki di sistem yang baru.

Mengidentifikasi masalah dilakukan dengan mengidentifikasi akar masalah, merupakan sumber dari permasalahan yang harus diperbaiki. Untuk mengidentifikasi masalah menggunakan cara analisis dengan kerangka PIECES (Performance, Information, Economic, Control, Efficiency dan Service) (Fatta, 2007). Kerangka PIECES digunakan untuk mengkategorikan permasalah sesuai dengan data yang dikumpulkan.

Performance (kinerja), ditemukan permasalahan utamanya berkaitan dengan penyusunan laporan keuangan dari masing-masing unit tidak terdapat kesesuaian format dan sering terjadi keterlambatan. Ketidaksesuaian format menjadikan laporan sulit di analisis dan keterlambatan pengiriman laporan dikarenakan proses penyusunan laporan masih dilakukan secara manual sehingga berpotensi menimbulkan kesalahan dan membutuhkan waktu yang cukup lama.

Information (informasi), informasi berkaitan dengan perkembangan masing-masing lembaga di bawah pengelolaan yayasan kurang terjamin. Keakurasian berkaitan dengan penyajian data keuangan belum sesuai dengan standar akuntansi, data tagihan keuangan dan pembayaran oleh peserta didik. Kurang terjaminnya informasi dan pelaporan keuangan yang belum standar akuntansi, karena data diproses secara manual, sehingga sering dijumpai 
adanya selisih serta penyajian informasi berlangsung lama.

Economic (ekonomi), dari aspek ekonomi, data keuangan utamanya data tagihan dan pembayaran dari peserta didik belum dikelola dengan baik, berpotensi terjadinya kerugian, serta perencanaan dan pengelolaan keuangan tidak dapat dilakukan dengan baik.

Control (pengendalian), permasalahan yang ditemukan berkaitan dengan penyimpanan file/dokumen, kerahasiaan tidak terjamin dan tidak dikoordinasikan dengan baik, dokumen tercecer pada beberapa komputer mengikuti dimana staf saat itu bekerja, dokumen hilang terhapus atau terkena virus, belum dilakukannya backup data dengan baik.

Efficiency (efisiensi), media komunikasi dan penyampaian informasi pihak sekolah dilakukan dengan buku penghubung, undangan, pengumuman di mading, pengumuman langsung ke siswa di kelas atau pihak orang tua harus datang langsung ke sekolah.

Service (pelayanan), pelayanan sangat tergantung dengan staf bagian Tata Usaha, apabila terdapat salah satu staf yang tidak masuk menjadikan pelayanan terganggu utamanya pelayanan pada bagian keuangan, serta pelayanan tergantung pada jam layanan.

Dari hasil analisis sistem yang telah dilakukan, kemudian dilakukan perancangan sistem dan pembuatan sistem.

\section{3) Penyerahan Bantuan Peralatan}

Sesuai dalam pengajuan usulan kegiatan IbM, yaitu terdapat bantuan peralatan pada mitra, pengelola telah menyiapkan beberapa peralatan teknologi tepat guna yang dibutuhkan dalam pengelolaan manajemen yayasan. Penyerahan peralatan ini diserahkan oleh ketua program IbM M. Ridho, di terima langsung oleh ketua masing-masing perwakilan pengurus YPI Masalikil Huda (Gambar 4) dan YPI Miftahul Huda (Gambar 5), disaksikan oleh anggota.

Adapun peralatan yang diberikan yaitu 2 unit komputer server; 2 unit printer; Sistem Informasi Yayasan (SiYap), beserta manual operasional.

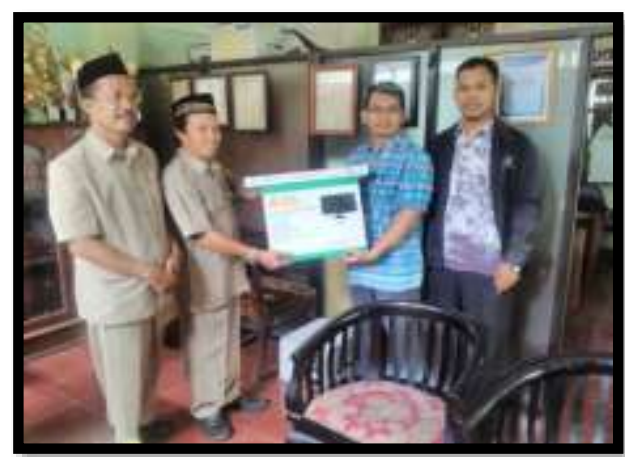

Gambar 4. Penyerahan bantuan peralatan kepada pengurus YPI Masalikil Huda Tahunan

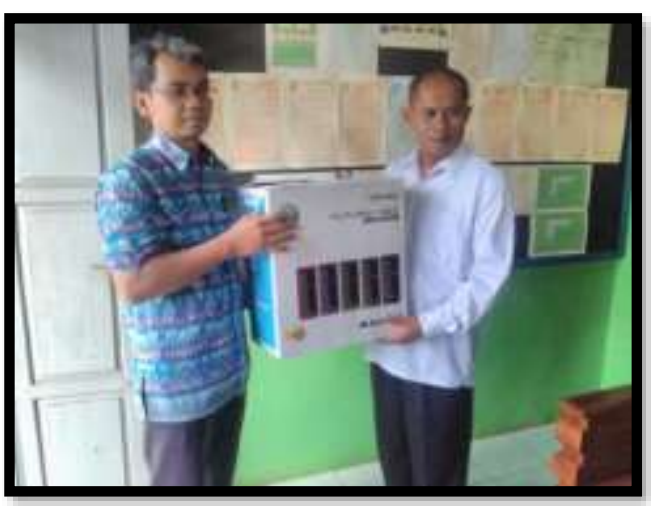

Gambar 5. Penyerahan bantuan perapatan kepada pengurus YPI Miftahul Huda

\section{4) Penerapan dan Proses Implementasi Aplikasi SiYap}

Implementasi sistem bertujuan untuk melakukan proses penerapan sistem baru supaya siap dioperasikan (Gambar 6). Tahap implementasi sistem yang dilaksanakan melalui beberapa tahapan, yaitu: 1) mempersiapkan rencana implementasi; 2) melakukan kegiatan implementasi; dan 3) menindaklanjuti implementasi (Jogiyanto, 2009).

Kegiatan implementasi sistem didahului dengan melatih personil yang ditunjuk sebagai administrator dan operator sistem, memilih dan mempersiapkan tempat dan lokasi sistem dalam hal ini ditempatkan pada sebuah komputer server yang telah disiapkan (Gambar 7). Sedangkan untuk proses konversi data dilaksanakan secara langsung, karena dari kedua yayasan sebelumnya belum memiliki basis data yang tersimpan di server, data-data yang ada konversi dari file-file yang tersimpan di Ms Excel, Ms Word maupun laporan cetak. 


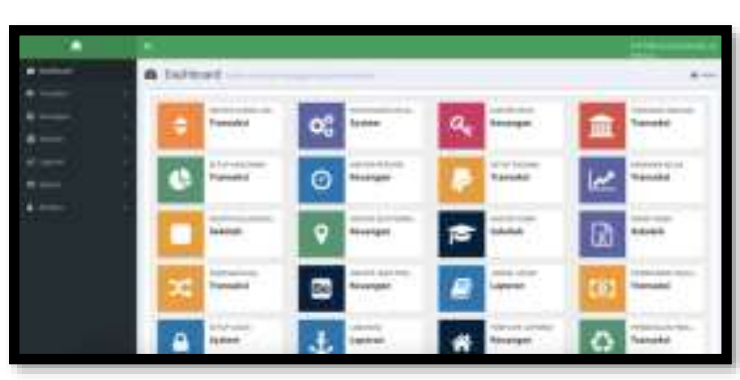

Gambar 6.

Dashboard Sistem Informasi Yayasan (SIYap)

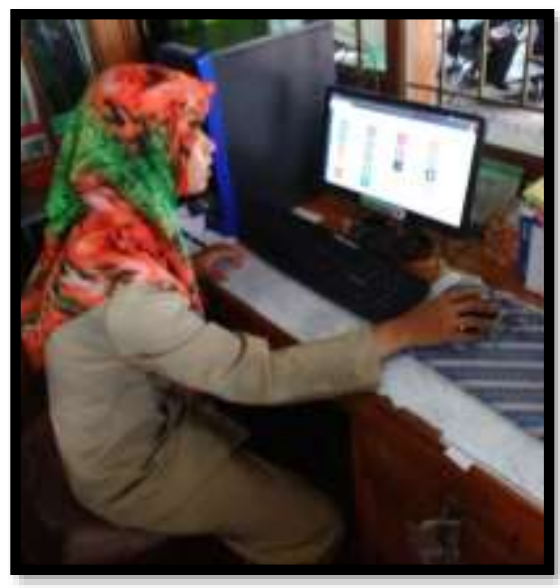

Gambar 7

Administrator SIYap di YPI Masalikil Huda menjalankan system

\section{5) Penyusunan dan Implementasi Prosedur Mutu}

Penyusunan Prosedur mutu dimulai dengan menggali informasi di yayasan, dengan melakukan koordinasi dan mengindefikasi kebutuhan yayasan, selain itu diidentifikasi alur kerja yang ada di yayasan. Setelah diketahui data yang dibutuhkan dan alur kerja maka pelaksana kemudian melakukan penyusunan panduan kerja yang terangkum dalam prosedur mutu.

Penyelesaian prosedur mutu dengan melibatkan pengelola dan pengurus yayasan untuk mendapatkan informasi alur kerja maupun ketentuan-ketentuan dalam menjalankan manajerial yayasan sehingga Prosedur Mutu akan dapat diaplikasikan sebagai acuan kerja.

Sosialisasi Prosedur Mutu dilakukan kepada pengurus maupun pengelola yayasan untuk memudahkan pengurus dan pengelola mengerti isi dan ketentuan-ketentuan yang ada dalam Prosedu Mutu yang telah disusun. Selain itu dalam sosialisasi juga mendengarkan masukan-masukan yang dapat digunakan untuk memperbaiki Standar Kerja yang telah dibuat.
Sosialiasi bertujuan untuk memberikan informasi yang ada di Prosedur Mutu yang telah disusun dengan adanya sosialisasi Prosedur Mutu tersebut terlihat jelas bahwa pengurus maupun pengelola yayasan mampu memahami dengan baik, hal ini terlihat karena dilibatkannnya sebagian pengurus maupun pengelola yang menyusun Prosedur Mutu.

\section{6) Pendampingan dan Penerapan Manajemen Tata Kelola}

Pendampingan dilaksanakan untuk memastikan bahwa Prosedur Mutu yang disusun telah dilaksanakan oleh pengelola dengan baik. Dengan dilaksanakannya pendampingan tersebut pengelola merasa terbantu dalam melaksanakan pekerjaan yang sesuai dengan standar operasional. Pengelola merasa tidak terbebani oleh prosedur yang telah disusun, karena Prosedur Mutu disusun dengan memperhatikan masukan dari pengelola tentang cara kerja yang ada di yayasan.

\section{KESIMPULAN DAN SARAN}

\subsection{Kesimpulan}

Dari hasil pelaksanaan pengabdian kepada masyarakat yang telah dilaksanakan dapat ditarik kesimpulan, sebagai berikut:

1) Seluruh tahapan program pengabdian masyarakat meliputi Pengembangan sistem informasi yayasan (SIYap); Penerapan dan Proses implementasi aplikasi SIYap; Penyusunan prosedur mutu tatakelola keuangan; Implementasi prosedur mutu tatakelola keuangan; serta pendampingan dan penerapan manajemen tatakelola keuangan telah dilaksanakan dengan baik, dengan output luaran berupa aplikasi SIYap versi 0.1 dan dokumen Prosedur Mutu pengelolaan keuangan dan kelembagaan yayasan.

2) Pengelolaan keuangan yayasan saat ini telah menggunakan sistem terkomputerisasi, melalui implementasi SIYap maka akan dapat meningkatkan efisiensi dan efektivitas operasi dan mengurangi timbulnya kesalahan atau manipulasi dalam sistem akuntansi. Laporan keuangan telah disajikan dengan baik, tepat waktu dan akurat melalui sistem.

3) Mekanisme pengelolaan keuangan dan kelembagaan telah diatur melalui berbagai prosedur mutu yang telah di susun, hal ini menunjukkan pelaksanaan tatakelola kelembagaan yang baik. Dengan implementasi tata kelola kelembagaan yang baik maka akan meningkatkan efisiensi dan efektivitas serta 
mengurangi timbulnya kesalahan dalam pengelolaan yayasan.

\subsection{Saran}

Berdasarkan pada hasil kesimpulan, maka dapat diberikan saran atas apa yang telah dicapai melalui program pengabdian kepada masyarakat ini, agar dapat dikembangkan lebih baik lagi.

1) Administrator sistem yang telah ditunjuk agar dapat mengkoordinasikan penggunaan SIYap kepada seluruh user/pengguna sistem, untuk berjalannya aktivitas pengelolaan keuangan melalui implementasi sistem informasi;

2) SIYap selanjutnya agar dapat dikembangkan lagi sesuai kompleksitas kebutuhan pengelolaan keuangan yang ada di yayasan, dalam hal ini dapat bekerjasama dengan pihak UNISNU Jepara maupun pihak-pihak lainnya yang bergerak dalam bidang pengembangan system informasi.

3) Prosedur Mutu pengelolaan keuangan dan kelembagaan yayasan agar dapat dilaksanakan secara konsisten, dan dilakukan perbaikan pada berbagai proses yang dirasa sudah tidak lagi sesuai dengan kompleksitas pengelolaan keuangan dan kelembagaan, serta kedepan perlu dilakukannya peninjaun prosedur secara berkala sehingga ada perbaikan berkelanjutan atas proses yang berjalan.

\subsection{Ucapan Terimakasih}

Program pengabdian yang dilaksanakan merupakan skema pengabdian Iptek Bagi Masyarakat (IbM). Dengan telah selesainya program kami tim pengabdian mengucapkan terimakasih kepada:
1) Kementrian Ristek DIKTI, Direktorat Riset dan Pengabdian Kepada Masyarakat yang telah mendanai pelaksanaan program pengabdian kepada masyarakat ini;

2) Lembaga Penelitian dan Pengabdian Kepada Masyarakat (LPPM) Universitas Islam Nahdlatul Ulama (UNISNU) Jepara yang telah mengkoordinir pelaksanaan kegiatan pengabdian kepada masyarakat;

3) Kepala sekolah MA Masalikil Huda Tahunan Jepara dan Kepala MI Miftahul Huda Sinanggul Jepara, sebagai mitra program dalam pelaksanaan program IbM, dan telah secara aktif ikut berpartisipasi dalam program pengabdian ini.

\section{REFERENSI}

Jogiyanto. (2009). Sistem Teknologi Informasi (Vol. III). Yogyakarta: Andi Publishing.

Fatta, H. A. (2007). Analisis dan Perancangan Sistem Informasi untuk Keunggulan Bersaing Perusahaan dan Organisasi Modern (Vol. I). (A. H. Triyuliyana, Ed.) Yogyakarta: CV. Andi Offset .

Karyono. (2013). Forensic Fraud (Vol. I). (D. Harjdono, Ed.) Yogyakarta: CV Andi Offset.

Brown, N. P. (2014). The effect of internal control regulation on earnings quality: Evidence from German (Vol. 33). Journal of Accounting and Public Policy.

Almasarwah, A. (2015). Earnings management and its relationship with corporate governance mechanisms in Jordanian industrial firms. Loughborough University, Accounting Department. Loughborough University's Institutional Repository. 